This item was submitted to Loughborough's Research Repository by the author.

Items in Figshare are protected by copyright, with all rights reserved, unless otherwise indicated.

\title{
8000 years of North Atlantic storminess reconstructed from a Scottish peat record: implications for Holocene atmospheric circulation patterns in Western Europe
}

\section{PLEASE CITE THE PUBLISHED VERSION}

https://doi.org/10.1002/jqs.2983

\section{PUBLISHER}

(c) Wiley-Blackwell

\section{VERSION}

AM (Accepted Manuscript)

\section{PUBLISHER STATEMENT}

This work is made available according to the conditions of the Creative Commons Attribution-NonCommercialNoDerivatives 4.0 International (CC BY-NC-ND 4.0) licence. Full details of this licence are available at: https://creativecommons.org/licenses/by-nc-nd/4.0/

\section{LICENCE}

CC BY-NC-ND 4.0

\section{REPOSITORY RECORD}

Stewart, Helena, Tom Bradwell, Joanna E. Bullard, S.J. Davies, Nicholas R. Golledge, and Robert McCulloch. 2019. "8000 Years of North Atlantic Storminess Reconstructed from a Scottish Peat Record: Implications for Holocene Atmospheric Circulation Patterns in Western Europe". figshare. https://hdl.handle.net/2134/25983. 
$5{ }^{1}$ Biological \& Environmental Sciences, University of Stirling, Stirling, FK9 4LA, Scotland, UK.

${ }^{2}$ Department of Geography, Loughborough University, Loughborough, LE11 3TU, England, 7 UK.

${ }^{3}$ Department of Geography and Earth Sciences, Aberystwyth University, SY23 3DB, Wales, UK.

${ }^{4}$ Antarctic Research Centre, Victoria University of Wellington, Wellington 6140, New Zealand.

*Corresponding author: robert.mcculloch@stir.ac.uk

ABSTRACT: North Atlantic storminess can affect human settlements, infrastructure and

transport links, all of which strongly impact local, national and global economies. An

increase in storm frequency and intensity is predicted over the Northeast Atlantic in the $21^{\text {st }}$

century because of a northward shift in storm tracks and a persistently positive North

Atlantic Oscillation (NAO), driven by recent atmospheric warming. Although documentary

records of North Atlantic storminess exist, these are generally limited to the last c. 1000-

2000 years. This paper presents a continuous high-resolution proxy record of storminess spanning the last 8000 years from a $6 \mathrm{~m}$ long core taken from a peat bog in Northern Scotland. Bromine concentrations in the peat, derived from sea spray, are used to reconstruct storm frequency and storm intensity, and mire surface wetness is used as an 
indicator of longer-term climate shifts. The results suggest a relationship between positive phases of the NAO and increased North Atlantic storminess. However, subtle differences between bromine concentrations and mire surface wetness suggest that high intensity but perhaps less frequent periods of storminess are not necessarily associated with a wetter climate.

KEYWORDS: Holocene storminess; NAO; micro-XRF; mire surface wetness; Scotland.

\section{Introduction}

The location and intensity of mid-latitude storm tracks strongly influence the climate of Europe (Hanna et al., 2008). The most intense and damaging storms affecting Europe originate in the North Atlantic, often causing extensive flooding and damage to infrastructure, and resulting in significant detrimental economic impacts. The highest magnitude storms occur most frequently during winter, when the storm tracks are most intense, and extend in a north-westerly direction from the east coast of North America, to Ireland, Great Britain and Norway (Cheng et al., 2011). North Atlantic storminess has increased over recent decades in association with warming air temperatures over the same period (Alexander and Tett, 2005, Allan et al., 2009, Wang et al., 2009). Predictions suggest that over the next 100 years North Atlantic storm tracks will shift northwards and storm frequency will increase in the British Isles due to an intensified jet stream (Pinto et al., 2009; Orme et al., 2015). 
47 Records of past storminess have been reconstructed through both observational and

48 sedimentary (or palaeoenvironmental) records. Observational records tend to span the past few hundred years and are based on air temperature (Dawson et al., 2003), sea surface temperature (Hurrell, 1995) and wind speed (Clarke and Rendell, 2009; Dawson et al., 2010). In Europe and the North East Atlantic, proxy measures for increased wind strength include aeolian sand influx (de la Vega-Leinert et al., 2000; Clarke et al., 2002; Sommerville et al., 2003; de Jong et al., 2006; Clarke and Rendell, 2009; Tisdall et al., 2013), over-wash deposits in coastal lagoons (Sabatier et al., 2012), cliff-top storm deposits left by extreme waves (Hansom and Hall, 2009), marine records reflecting wind-blown current strength and storm deposits (Hass, 1996; Andresen et al., 2005). and $\mathrm{Na}^{+}$from the Greenland ice cores (Dawson et al., 2003). Paleoenvironmental reconstructions of North Atlantic storminess tend to span from the mid-Holocene to the present and so high-resolution records on a millennial timescale $\left(10^{3}\right.$ a) are an important goal in order to gauge longer-term trends and better understand Holocene climate variability.

The position and strength of the polar front jet stream in the Northern Hemisphere strongly determines the process of cyclogenesis between $\sim 40$ and $65^{\circ} \mathrm{N}$, and, therefore, the number and frequency of high-energy storms in the North Atlantic region (Fig. 1). The development of a vigorous jet stream in winter, enabled by strong temperature contrasts between mild moist mid-latitude and cold polar air, accounts for the strength and trajectory of dominant westerly winds as well as the frequency of extra-tropical storms and their tracks over northwestern Europe (Hurrell 1995, Hurrell et al., 2003; Athanasiadis et al., 2010). Secular changes in the North Atlantic Oscillation (NAO), defined as the sea-level pressure difference between the main North Atlantic pressure dipole measured in Iceland and the Azores, are strongly 
associated with changes in the polar-front jet stream (Hurrell 1995; Woollings et al., 2008, 2010). An enhanced NAO (positive) mode typically results from undisturbed strong zonal (east to west) jet stream flow between 50 and $60^{\circ} \mathrm{N}$; whilst a negative $\mathrm{NAO}$ mode results from disturbed, meridional flow with a large north-south component leading to blocking highs and cut-low pressure systems. During a negative NAO, the dominant westerly winds often follow a more southern trajectory owing to the development of a large quasi-stationary highpressure system over Greenland (Woolings et al., 2008, 2010). Both strongly positive and negative NAO modes represent end members and require relatively vigorous jet-streamdriven atmospheric circulation in the North Atlantic sector. These conditions are normally optimised during European winter, hence the strong positive correlation between NAO mode and winter precipitation in NW Britain and western Norway (Hurrell, 1995; Hurrell et al., 2003). However, other more subdued long-term synoptic situations can occur. These include a neutral NAO phase, where the pressure index is neither strongly positive nor strongly negative, normally associated with a weakening of the main Iceland cyclonic and Azores anticyclonic pressure systems. In this situation, the development of large persistent Scandinavian high-pressure systems can block the path of westerly winds into NW Europe, further reducing cyclonic activity and dampening the NAO index into a more neutral state (Mauri et al., 2014).

This paper presents chemical variability and palaeo-moisture indices from a six metre-long peat core in maritime Northern Scotland. Analyses of down-core variations in bromine concentrations as an indicator of storm intensity are coupled with mire surface wetness (MSW) as an indicator of longer-term storm-track position and climate shifts in the 
Northeast Atlantic. Finally, we compare our record to other proxies for shifts in the NAO during the Holocene.

\section{Bromine as an indicator of storminess}

The generation of sea-salt aerosol is the principal global source of atmospheric $\mathrm{Br}$, producing 6.2 Tg/a (Sanders et al., 2003). The bursting of air bubbles and the direct formation of droplets by wave crests injects sea-salt aerosol into the atmosphere and so the flux of $\mathrm{Br}$ is dependent on wind speed (Moldanová and Ljungström, 2001). Marine aerosols may be transported long distances (10s-100s km) and be dry deposited or scavenged from the atmosphere by rainfall (Gustafsson and Franzén, 2000). Other sources of inorganic $\mathrm{Br}$ are dust, biomass-burning and fossil fuels but these are of an order of magnitude less than marine sources. Crustal sources are estimated to be $4 \%$ of the global $\mathrm{Br}$ flux and its deposition is geographically restricted to the equatorial Atlantic and North Pacific Oceans (Sanders et al., 2003). Ombrotrophic peat bogs receive only atmospheric inputs and so provide excellent archives of climatic change. It has been argued that $\mathrm{Br}$ concentrations are determined by climate-controlled biogenic processes (Biester et al., 2004; Moreno et al., 2015) and are not stratigraphically retained. However, other studies have demonstrated that $\mathrm{Br}$ is stably retained in the humic acid content of peat and down- core variations are conserved (Zaccone et al., 2008; Orme et al., 2015; Turner et al., 2015). Br concentrations in peat bogs around the maritime fringes of the North Atlantic, such as in the British Isles, are very likely to be derived from sea spray; hence higher Br levels suggest an increase in sea turbulence, accentuated wave action, and increased windiness during storms. Mire surface wetness (MSW), an additional measure, indicates longer-term changes in precipitation 
patterns with increased MSW signalling a more persistent wetter climate (Charman et al.,

118 2006; Turner et al., 2014).

119

\section{Materials and methods}

121 Site description and field sampling

122 A continuous high-resolution peat core (to $6.08 \mathrm{~m}$ depth) was obtained from the central part of a large mire at Shebster, northern Caithness $\left(58^{\circ} 33^{\prime} 06.6^{\prime \prime} \mathrm{N}, 003^{\circ} 42^{\prime} 39.0^{\prime \prime} \mathrm{W} ; 82 \mathrm{~m}\right.$ asl; $4.8 \mathrm{~km}$ from the North Atlantic coast) (Fig. 2). The mire surface is bordered by the Burn of Shebster that drains northwards. The bedrock underlying the site is Middle Devonian sandstone of the Bighouse Formation (Auton et al., 2005). The core was sampled from within the deepest part of the Shebster peat bog using a 1-metre long (75 $\mathrm{mm}$ diameter) Russian D-section sampler (with $10 \mathrm{~cm}$ overlapping sections). Recovered cores were transferred into plastic guttering, sealed in lay-flat tubing, and stored at the University of Stirling at a constant temperature of $4^{\circ} \mathrm{C}$.

Minerogenic analysis

The core was sub-sampled in contiguous $2 \mathrm{~cm}^{3}$ sections for acid digestion to remove organic matter (c.f. Dugmore et al., 1995a). The mineral residue was then scanned using light microscopy to identify tephra glass shards to supplement the radiocarbon chronology with tephrochronology. 
To provide a record of bio-productivity and organic content, contiguous samples of $2 \mathrm{~cm}$ depth were combusted in a muffle furnace at $550^{\circ} \mathrm{C}$ for 4 hours to enable the calculation of the percentage loss-on-ignition ( $\left.\mathrm{LOI}_{550}\right)$.

\section{Mire surface wetness}

The degree of peat humification, as a proxy of MSW, was estimated using the colorimetric alkali extract method modified from Blackford (1993). Under drier conditions peat is more oxidised, the accumulation rate is slower and there is an increase in humic material. The greater the humic content the darker the extract solution and the lower the transmitted light values. Therefore, lower percentage transmission values indicate drier peat accumulation conditions whereas higher percentage transmission values indicate wetter conditions. Contiguous sub-samples of $2 \mathrm{~cm}^{3}$ were taken from the $608 \mathrm{~cm}$ core. Samples were oven dried at $80^{\circ} \mathrm{C}$ for $24 \mathrm{hrs}$ and then ground using a small rotating blade grinder. Sub-samples of $0.2 \mathrm{~g}$ were placed into $50 \mathrm{ml}$ falcon centrifuge tubes and $50 \mathrm{ml}$ of $\mathrm{NaOH} 8 \%$ $\mathrm{w} / \mathrm{v}$ was added to each sample and the tubes placed in a boiling water bath for 60 minutes and intermittently stirred. The samples were then centrifuged at $3000 \mathrm{rpm}$ for 5 minutes and a $0.5 \mathrm{ml}$ aliquot pipetted into a $10 \mathrm{~mm}$ cuvette and $2.5 \mathrm{ml}$ of distilled water added. The cuvettes were analysed in a Thermo Scientific Genesys 20 spectrophotometer and the percentage transmitted light measured at $540 \mathrm{~nm}$. This method allowed for batches of 20 samples to be analysed in under $30 \mathrm{~min}$. from removal from the water bath and so minimise any fading of the solution (cf. Blackford, 1993). 
The core was analysed using an Itrax ${ }^{\circledR} X$-Ray Fluorescence core scanner at Aberystwyth

University. Non-destructive elemental analysis, including $\mathrm{Br}$ was performed at $2 \mathrm{~mm}$ intervals using a molybdenum (Mo) anode X-ray tube (settings: $30 \mathrm{kV}, 50 \mathrm{~mA}$, count time 10 seconds). The results are expressed as a ratio of the coherent+incoherent (coh/incoh) values, which are used as proxies for organic and moisture content. The coh/incoh ratio minimises any influence from these proxies on the geochemical data. Density and colour information was further obtained using X-radiography and digital RGB optical imagery.

\section{Chronology}

Five samples of wood material were AMS radiocarbon dated to enable the construction of a Bayesian age-depth model. All samples were pre-treated with an acid/alkali/acid treatment. To augment the radiocarbon chronology, a cryptotephra layer (346 cm depth) was analysed through the geochemical fingerprinting of individual shards by the SX100 Cameca Electron microprobe at the University of Edinburgh using methods established by Hunt and Hill (1993) and Hayward (2013).

The cryptotephra at $346 \mathrm{~cm}$ is geochemically correlated to the eruption of Hekla 4 (Tephrabase; Newton, 1996) and provides an isochronic marker dated to $3826 \pm 12{ }^{14} \mathrm{C}$ a BP (Dugmore et al. 1995b). The AMS radiocarbon and tephra ages were calibrated using Calib ver.7.10 (Stuiver and Reimer, 1993) and IntCal13 (Reimer et al., 2013)(Table 1). The Bayesian program, BACON v2.2 (Blaauw and Christen, 2011) was used to construct an agedepth model to constrain the stratigraphic results (Fig. 3). The age-depth model indicates a mean accumulation rate of $13 \mathrm{yrs} / \mathrm{cm}$ and a uniform rate of peat accumulation during the Holocene. 


\section{Results}

From 612 to $608 \mathrm{~cm}$ depth greyish-brown organic mud grades to a dark brown moderately humified peat (with wood fragments at $404-406 \mathrm{~cm}$ depth) that continues to $\sim 370 \mathrm{~cm}$. From $\sim 370$ to $271 \mathrm{~cm}$, the core comprises very dark brown well-humified amorphous peat.

At $271 \mathrm{~cm}$, there is a marked transition to a dark brown peat with abundant sedge fragments. The sedge-rich peat continues to $27 \mathrm{~cm}$ and is moderately well humified and with occasional wood fragments. From $27 \mathrm{~cm}$ to the surface root mat, the core comprises a dark brown fibrous sphagnum peat.

To aid the interpretation, the Shebster stratigraphic data is divided into 8 major zones based on major changes in the MSW as this is a site-specific proxy (Fig. 3).

SH-1 $8210-7400 \mathrm{cal}$ a BP: MSW was not measured in the lowest $\sim 10 \mathrm{~cm}$ of the peat to avoid any potential influence from the underlying lake sediments; measurements commenced at $590 \mathrm{~cm}$. In Zone SH-1 the MSW curve is characterised by two peaks at $c$. 7960 and $7610 \mathrm{cal}$ a BP, separated by a nadir at c. $7740 \mathrm{cal}$ a BP. The Br ratios appear to be in antiphase with the largest peak of the entire record occurring at $c .7800$ cal a BP, before both MSW and bromine decline to a low at the upper zone boundary at c. 7400 cal a BP.

SH-2 $7400-5270$ cal a BP: At the start of this zone there is a marked step up to higher MSW values that fluctuate (between 20 and $30 \% \mathrm{~T}$ ) through the first half of the zone. $\mathrm{Br}$ values commence from a peak between c. 7400 and $7300 \mathrm{cal}$ a BP and then decline to a broad low 
also during the first half of the zone, between c. 7300 and $6200 \mathrm{cal}$ a BP. At c. $6145 \mathrm{cal}$ a BP

there is a rapid increase in $\mathrm{Br}$ to a sustained peak until a fall at c. 5700 to lower but

fluctuating values and then increasing towards the upper zone boundary. The MSW values in the second half of the zone also continue to fluctuate (between 25 and $35 \% \mathrm{~T}$ ) but at higher values than previously.

214

SH-3 5200 - 4000 cal a BP: Br increase to a peak between c. 5200 and 4900 cal a BP followed by a sustained declining trend towards the upper zone boundary at $c .4000 \mathrm{cal}$ a BP. The decline in $\mathrm{Br}$ is reflected in a similar profile in the MSW, excepting a brief minor peak in MSW at c. 4540 cal a BP.

SH-4 4000 - 3300 cal a BP: The Br ratios reach their minima at c. 3850 cal a BP and remain relatively stable before gradually increasing from c. $3400 \mathrm{cal}$ a BP to a peak at the upper record before rising again at the top of the zone. continue to rise to $\sim 30 \%$, punctuated by a brief decline to $17.5 \% \mathrm{~T}$ at $c .3005 \mathrm{cal}$ a BP. $\mathrm{Br}$ values remain relatively stable, with small fluctuations occurring throughout this period. and $\mathrm{Br}$ values continue to be relatively stable. 
SH-7 $1400-600$ cal a BP: Br ratios peak between c. 1225 and 1130 cal a BP and between c. 855 and $750 \mathrm{cal}$ a BP before declining to a low at c. $600 \mathrm{cal}$ a BP. MSW values increase to a peak at c. $1365 \mathrm{cal}$ a BP (39.1\%T) then decline to a low at c. $1115 \mathrm{cal}$ a BP (18.0\%T) followed by peaks at c. $950(34.1 \% \mathrm{~T})$ and $675 \mathrm{cal}$ a BP (34.8\%T).

SH-8 600-0 cal a BP: MSW values decline to a low at c. 300 cal a BP (18.8 \%T) before rising to a peak of $43.3 \%$ T at c. 140 cal a BP. In contrast, $\mathrm{Br}$ values rise rapidly to a sustained peak between c. 380 and 200 cal a BP.

\section{Discussion}

The down-core variations in $\mathrm{Br}$ and MSW indicate that changes in $\mathrm{Br}$ concentrations likely reflect longer-term changes in storminess in the NE Atlantic rather than biogenic processes within the peat bog. Therefore, our $\sim 8000$ year palaeo-wetness and storminess record from Shebster, Northern Scotland, can be interpreted alongside other key proxy records from around the North Atlantic to place the inferred palaeoenvironmental trends in a wider context of Holocene atmospheric circulation changes. These proxy records include: a 5000 year glacier record from Folgefanna in Southern Norway (Bakke et al., 2008); a reconstructed 5000 year NAO index based on a lake-sediment core in SW Greenland (Olsen et al., 2012); a Scottish speleothem record (Baker et al., 2015); and an Iberian speleothem record (Walkzak et al., 2015) (Fig. 4). Variations in speleothem laminae thickness provide an annual growth-rate record that can be used as a proxy for past climate and environmental change. Growth rates are determined by changes in precipitation and higher growth rates suggest warmer and wetter conditions (positive NAO state) whereas low growth rates are 
associated with colder and drier conditions (negative NAO state) (Baker et al., 2015). The

NAO index based on a south-west Greenland lake-sediment core is reconstructed from deep-water anoxia data (Olsen et al., 2012). A negative NAO is associated with above average temperatures and below average winter precipitation, leading to earlier ice melt and allows stronger vertical mixing of the water column. This weakens thermal stratification and hence increases oxygen transfer into the deep-water zone, with associated implications for redox processes. A positive NAO, associated with colder conditions, leads to later ice melt, which coincides with maximum solar radiation and results in limited water column mixing. This leads to the rapid onset of thermal stratification, and hence maintenance of hypoxic conditions. Deep-water anoxia can alter cycling of redox-sensitive elements. The $\mathrm{Mn} / \mathrm{Fe}$ ratio reflects the strength of seasonal thermal stratification and is therefore a proxy for dominant NAO circulation patterns. A higher $\mathrm{Mn} /$ Fe ratio and carbonate concentration and is associated with positive NAO conditions.

SH-1 $8210-7400 \mathrm{cal}$ a BP: To avoid the influence of any mineral material from the underlying lacustrine sediments the degree of peat humification was not analysed at the base of the peat $(608 \mathrm{~cm})$. The lowest part of the available record is characterised by several high magnitude fluctuations in wetness and storminess. Although the base of the analysed peat record starts at c. 8200 cal a BP, neither the $\mathrm{Br}$ record nor the MSW data completely capture the $8.2 \mathrm{ka}$ event, expressed as a marked rapid negative temperature anomaly across much of the Northern Hemisphere (Larsen et al., 2012; Tipping et al., 2012). However, SH-1 is dominated by a large Br positive anomaly centred at $c .7800 \mathrm{cal}$ a BP, suggesting a period of enhanced 
storminess lasting c. 300-400 years. By contrast, the humification record at this time suggests conditions of below-average wetness. This anti-phase relationship between $\mathrm{MSW}$ and $\mathrm{Br}$ appears paradoxical, but may suggest that these storms were cold, moisture-starved Polar vortex systems rather than moisture-bearing westerly winds. This is supported by the Iberian speleothem record, which shows a stable, positive record indicating warmer and wetter conditions. Rainfall in southern Iberia was more evenly distributed throughout the year, typical of a more temperate climate lacking a clear dry season (Walczak et al., 2015) and may indicate a more southerly position of the jet stream and, therefore, a persistent negative NAO phase (phase B1, Fig. 1).

SH-2 7400-5270 cal a BP: After c. 7400 cal a BP there was a marked increase in MSW at Shebster and although the values fluctuate during the period between c. 7400 and $6200 \mathrm{cal}$ a $\mathrm{BP}$, they remain high suggesting the persistence of wetter conditions. However, $\mathrm{Br}$ values decrease from the initial peak in zone $\mathrm{SH}-1$ which may suggest that although this zone reflects wetter conditions storminess was less intense than in $\mathrm{SH}-1$. This period probably indicates a northerly migration of the jet-stream-driven westerly winds accompanied by a movement of the North Atlantic storm tracks to a position located over Northern Scotland. This atmospheric circulation pattern is best described by the positive mode of the NAO (phase A, Fig. 1).

In the second half of SH-2, from c. 6200 to 5270 cal a BP, MSW continues to reflect increased and more sustained wetter conditions. At the same time, $\mathrm{Br}$ values remain high indicating higher levels of storminess throughout this period. A pronounced peak in storminess occurs in zone SH-2 between c. 6145 and 5700 cal a BP. It is not certain what might have caused this 400-year window of increased storminess, during a period of relatively wetter but more 
stable climatic conditions. The Iberian speleothem record is characterised by a decline in growth rates between 6100 and 5300 cal a BP suggesting decreased moisture availability (Walczak et al., 2015) and this is consistent with a stronger polar-front jet stream bringing an increase in the number and intensity of storms tracking over Northern Scotland (i.e. a strongly positive NAO mode).

309

SH-3 5270-4000 cal a BP: Between c. 5300 and 4000 cal a BP, MSW and Br values reflect a synchronised period of gradual and near-continuous decline in both precipitation and storminess over Northern Scotland. Several proxy records reflect a mixed climate signal at this time. The glacier-ELA-reconstructed winter precipitation record from Bakke et al. (2005) indicates a comparable near-continuous decrease in wetness over most of this period (c. $5000-4000$ cal a BP) and is consistent with the Iberian speleothem record which also shows a shift to drier conditions with the exception of an increase in wetness at c. 4200 cal a BP. This climate period is also captured by the earliest part of the SW Greenland lake-sedimentreconstructed NAO index, which shows a sustained positive NAO phase between c. 5200 and 4400 cal a BP (Olsen et al., 2012). These climatic conditions are all compatible with a period of geographically unstable jet stream position and/or declining jet stream strength bringing generally warmer, drier summer conditions to NW Europe accompanied by a decline in cyclogenesis with fewer storms tracking across northern Scotland. After c. 4400 cal a BP, the reconstructed NAO index (Olsen et al., 2012) enters a relatively neutral phase consistent with a decrease in jet stream vigour, at a time when the Shebster peat record indicates steadily decreasing North Atlantic storm activity. 
SH-4 4000-3300 cal a BP: This period marks the most striking departure in the Shebster peat record when MSW and $\mathrm{Br}$ values are at their lowest for the entire 8000-year record. We relate these values to a sustained period of relatively drier climate and greatly reduced storminess following on from the decline in storminess seen in the preceding millennium (c. 5300-4000 cal a BP; SH-3). A marked decrease in North Atlantic storminess in Northern Scotland could be associated with two different atmospheric circulation scenarios: (1) westerly wind and storm-track migration to a more southerly latitude (ca. $40^{\circ} \mathrm{N}$ ) equating to a strongly negative winter NAO phase; (2) reduced jet stream strength and a low-value or neutral NAO phase. This period of unusual drier and calmer climate identified in the Shebster peat record is not restricted to Caithness, but is probably the expression of a panEuropean/North Atlantic event seen widely in other Holocene palaeo-climate proxies. Peat surface-wetness records from a composite of 12 sites in Northern Britain (Charman et al., 2012) show a period of considerably decreased wetness from c. 3900 to $3400 \mathrm{cal}$ a BP, the most pronounced in the mid to Late Holocene (interrupted by a brief increase in wetness at c. 3750 cal a BP). In southern Europe, often in antiphase with the climate of northern Britain, Mediterranean records from south-eastern Italy to south-western France record a period of relatively drier conditions between c. 4000 and 3400 cal a BP (e.g. Di Rita and Magri, 2009; Genty et al., 2006; Walczak et al., 2015), and this can also be seen in the Iberian speleothem record. Further afield, in continental North America and Mexico declining monsoon strength are recorded in a number of geographically diverse proxies from c. 4200 to 3500 cal a BP (Booth et al., 2005; Metcalfe et al., 2015). This is also coincident with the marked southerly migration of the ITCZ (c. $4000 \mathrm{cal}$ a BP) seen in a number of low-latitude records, including the high-resolution Cariaco Basin (Haug et al., 2001; Metcalfe et al., 2015). Closer to Scotland, the same SH-3 time interval (c. 4000-3300 cal a BP) sees lower than present precipitation in 
the Norwegian glacier record (Bakke et al., 2005); whilst temperatures in south-west Ireland inferred from speleothems show a broad thermal minimum c. 3800 to 3400 cal a BP (McDermott et al., 2001). It is notable that this period is also characterised by a marked negative departure in chlorine in the GISP2 record, inferred as a weakening of the Icelandic al., 2004).

The collected multi-proxy evidence from both sides of the North Atlantic points towards jet stream weakening during $\mathrm{SH}-4$, leading to a decrease in cyclonic activity which reaches a minimum at c. $3800 \mathrm{cal}$ a BP. Negative NAO conditions normally result in increased rainfall and storminess over southern Europe (e.g. Hurrell et al., 2003; Pinto et al., 2009), something that is not seen in most of the proxy records between c. 4000 and 3300 cal a BP (see above). Secondly, negative NAO phases have been strongly linked with meridional airflow and strong temperature contrasts causing enhanced but intermittent cyclogenesis in north-west Europe (Trouet et al., 2012; Vliet-Lanoë et al., 2014). Again, this is not evident in the Shebster record during $\mathrm{SH}-4$, with storm-driven $\mathrm{Br}$ values reaching their 8000 -year minimum within this time window. However, these observations, in combination with a prolonged neutral phase of the reconstructed NAO index (Olsen et al., 2012), are entirely consistent with a decrease in jet stream vigour during $\mathrm{SH}-4$. We would expect that this period experienced considerably reduced westerly (zonal) airflow at $50-60^{\circ} \mathrm{N}$, accompanied by a higher incidence of quasistationary high-pressure systems over Northern Europe. There is evidence from the Shebster $\mathrm{Br}$ and MSW data that this c. 700-year period of subdued westerly winds (reduced jet stream vigour) and cyclogenesis over northern Scotland is the ultimate expression of a declining trend in storminess and wetness that started at c. 4500 cal a BP (in SH-3), coincident with the switch 
from positive to low-value or neutral NAO values $(<1.0)$ in the Greenland sediment record (Olsen et al., 2012).

SH-5 $3300-2400$ cal a BP: A marked broadly synchronous increase in MSW and Br values at c. 3200-3300 cal a BP indicates the return to wet and stormy conditions in northern Scotland. This period (SH-5) is characterised by generally increasing MSW levels throughout (c. 3300$2400 \mathrm{cal}$ a BP) and a relatively high but fluctuating storminess index. Supporting proxy data suggest more vigorous cyclogenesis, increased precipitation and raised water tables in northwest Europe at this time (Hughes et al., 2000; Charman, 2010; Swindles et al., 2007; Oldfield et al., 2010), although the reconstructed NAO index displays a strong fluctuation from initially positive (c. $3300-3000$ cal BP) to strongly negative values (c. $3000-2400$ cal a BP) (Olsen et al., 2010). A marked concomitant rise in air temperatures and winter precipitation, seen in the Irish speleothem, Norwegian glacier and Iberian speleothem proxy-records (Fig 4) between c. 3300 and $2700 \mathrm{cal}$ a BP would also suggest a return to more dynamic atmospheric circulation patterns over north-west Europe with strongly zonal moisture-bearing winds and more moderate levels of cyclogenesis.

The most sustained period of negative NAO in the Greenland lake-sediment record is synchronous with an increase in MSW at Shebster (c. 2800-2400 cal a BP). This probably relates to a strengthening of the westerly winds (after the quiescent SH-4 phase) and a mean storm track positioned to the south of Scotland, consistent with the relative decrease in storminess at this time. The annually resolved north-west Scotland speleothem record also starts during this time (Baker et al., 2015). Although no overall trend in the composite speleothem climate-index is apparent during the first 500 years, relatively high-magnitude 
401

402

peaks in speleothem growth rates at c. 2900 and 2600 cal a BP probably reflect decadal to centennial periods of higher precipitation in northern Scotland (Baker et al., 2015).

At c. 3000 cal a BP glaciers become permanently established at some marginal sites in Iceland, Norway and southern Greenland for the first time since their complete disappearance in the early Holocene (c. 8000-7000 cal a BP) (Andresen \& Bjork, 2005; Balascio et al., 2015; Larsen et al., 2012). Numerous other studies have linked this renewed ice growth, or Neoglaciation, with a shift towards wetter and/or cooler climate in Northern Hemisphere higher latitudes after c. 4200 cal a BP (Blaauw et al., 2004; Swindles et al., 2007; Wang et al., 2012).

SH-6 2400-1400 cal a BP: During this period MSW at Shebster remains relatively high whilst

Br levels are somewhat subdued (close to, but slightly below the 8000 -year mean), continuing the long-term trend established in SH-5. The north-west Scotland speleothem record exhibits high growth rates suggesting moist but more stable climatic conditions. Elsewhere around Europe this millennium is synonymous with the 'Roman Warm Period' (2500-1600 cal a BP) (Wang et al., 2012) and is characterised by a predominantly positive (>1.0) NAO index in Greenland (Olsen et al., 2012). This strong pressure dipole, but relatively stable low-storm index state, suggests a poleward shift of the westerly storm tracks to a position between Iceland and Scotland, as seen during positive NAO summers. However, the low storm index suggests a more complex relationship, possibly with an increased polar front latitudinal range in winter with storms tracking to the south of northern Scotland. Support for this hypothesis comes from a peat record from Cors Fochno, mid Wales where sustained higher $\mathrm{Br}$ values between c. 2200 and $1600 \mathrm{cal}$ a BP suggest that although the 
Roman Warm period was comparatively dry at Shebster in Northern Scotland, North

Atlantic storms still tracked across central and southern Britain with relatively high frequency (Orme et al., 2015).

SH-7 1400-600 cal a BP: This period includes the Medieval Climate Anomaly (MCA: 700-1100 cal a BP; Mann and Jones, 2003) and is characterised at Shebster by higher but variable MSW alongside relatively higher and variable $\mathrm{Br}$ levels in the peat record. Together they suggest a wetter and stormier period in Northern Scotland than the previous millennium (SH-6) which is consistent with the unusually long and unbroken, strongly positive, NAO phase (Trouet et al., 2009). This is seen in the Greenland lake-sediment record from c. 1400 to 600 cal a BP (Olsen et al., 2012). A positive NAO mode is normally associated with a vigorous jet stream and a North Atlantic winter storm track focused between $55-60^{\circ} \mathrm{N}$ (at the latitude of northern mainland Scotland) (Hurrell et al., 2003; Woollings et al., 2008, 2010). This circulation pattern is supported by several other palaeoenvironmental proxies from the British Isles and adjacent areas. Firstly, the composite British peat-surface wetness record compiled by Charman (2010) shows a continuous phase of elevated water tables spanning the entire 800-year period with a peak c. 1100-1200 cal a BP. Secondly, the Irish speleothem record shows several centuries of increasing above-average (inferred) temperatures, with a peak c. 700-900 cal a BP (McDermott et al., 2001). Thirdly, the winter moisture index from Norwegian glaciers shows well above-average precipitation (120-140\% present day) in this time interval (Bakke et al., 2008). Fourthly, the occurrence of outsized wave-transported boulders (cliff-top storm deposits) 15-60 m above sea level in Shetland, northern Scotland, dated to between c. 1300 and 800 cal a BP (Hansom and Hall, 2009), indicate enhanced storminess at $\sim 60^{\circ} \mathrm{N}$. Finally, lower values of $\mathrm{Br}$ at Cors Fochno peat bog, relative to the preceding period (Orme et al., 
2015), suggest that the main westerly storm tracks were not focused at the latitude of mid Wales $\left(52^{\circ} \mathrm{N}\right)$ but further north over Scotland. However, more complexity is introduced when comparing these proxy records with growth rates from the north-west Scotland speleothem record. Baker et al. (2015) reconstruct strongly negative NAO-like conditions from c. 1400 to $1100 \mathrm{cal}$ a BP, at which point the trend is reversed and their reconstruction shows a strongly positive phase throughout the MCA, similar to the Olsen et al. (2012) NAO record. Therefore, we interpret the MCA period to be one of a strong polar-front jet stream and enhanced cyclogenesis, bringing westerly storms tracking across northern Scotland $\left(57-60^{\circ} \mathrm{N}\right)$. Although the variable antiphase relationship between $\mathrm{MSW}$ and $\mathrm{Br}$ records at Shebster perhaps suggest, at times, decreased storm frequency but higher storm intensity across the northern British Isles, consistent with the generation of high-energy storm deposits around northern Scotland's coasts (Hansom and Hall, 2009).

SH-8 600-0 cal a BP: The most recent period captured in the Shebster peat record spans from c. 600 to $100 \mathrm{cal}$ a BP and almost exactly corresponds to the Little Ice Age (LIA: c. 150-700 cal a BP; Mann and Jones, 2003). This period is characterised at Shebster by high but variable MSW and generally high $\mathrm{Br}$ values, indicating increased wetness and storminess for much of this 500-year window. A notable exception is the period between c. 100 and 200 cal a BP when $\mathrm{Br}$ (i.e. storminess) is subdued with levels equivalent to $\mathrm{SH}-6$. However, the cause of the LIA cooling (and/or any associated storminess) has been the source of considerable research and debate (Lamb, 1995; Orme et al., 2016; Trouet et al., 2012). A clear LIA signal is seen in the proxy-reconstructed NAO indices of Olsen et al. (2012) and Baker et al. (2015), where an abrupt shift from strongly positive to negative NAO occurs at c. 600 cal a BP in both records. The shift is larger and more sustained in the reconstruction provided by Baker et al. 
(2015). The record suggests that this dominantly negative NAO phase was associated with a vigorous jet stream, a higher incidence of moisture-bearing winds and a higher frequency of storms generally tracking across the latitude of Northern Britain $\left(55-60^{\circ} \mathrm{N}\right)$ for much of the LIA (c.100-600 cal a BP). The normal negative NAO configuration involves a significant southward shift in dominant westerly winds and storm tracks, to the latitude of southern France, northern Iberia and the western Alps $\left(40-45^{\circ} \mathrm{N}\right)$ (Woollings et al., 2008, 2010). However, other records from around Scotland show with a high level of certainty that the LIA period (esp. from 400-100 BP) was one of periodically enhanced storminess, increased sea state and wave activity, and generally disrupted weather patterns (Sommerville et al., 2003; Mcllvenny et al., 2013; Orme et al., 2016). These features are the hallmarks of an unusually turbulent period of atmospheric circulation, typically associated with disturbed jet stream strength and an unstable location (switching from zonal to meridional flow pattern), consistent with variable but high levels of Br-inferred storminess at Shebster (this study) and to a lesser degree at Cors Fochno (Orme et al., 2015) during the second half of the LIA. However, the speleothem and MSW records reflect a shift to relatively drier although perhaps less stable conditions. Again the contrast between the records of storminess and local wetness is probably due to the LIA being dominated by overall colder and drier conditions but affected by lower-frequency higher-intensity storm events (supporting the findings of Trouet et al., 2012).

\section{Conclusions}

The Shebster climate record provides insights into the timing and nature of North Atlantic climate changes and is a significant advance to the existing records in that it spans much of the Holocene. The combined $\mathrm{Br}$ and MSW records highlight the millennial to centennial scale changes in the position of the polar jet stream - a significant driver of environmental 
change in northern Scotland and the wider North Atlantic region. The Shebster climate record is consistent with the Norwegian glacier record, Greenland sediment-inferred NAO index, Scottish speleothem record and Iberian speleothem record but most importantly advances our understanding of the development and fluctuations of the NAO from the early Holocene. We infer from the data that periods of high Br and MSW levels probably relate to a jet stream position over Northern Scotland and, therefore, increased storminess and a positive $\mathrm{NAO}$ mode. Periods of reduced $\mathrm{Br}$ and mire wetness levels probably relate to a more southerly position of the jet stream and, therefore, a decline in storminess and a negative NAO. Between c. 4000 and $3300 \mathrm{cal}$ a BP there are very low levels of $\mathrm{Br}$ and mire wetness consistent with a drier period across much of the northern hemisphere which may relate to a neutral NAO state and a weaker jet stream. However, subtle differences between these two proxies suggest that single indicators of storminess may not be sufficient to reconstruct changes in jet stream movement and NAO index. These differences also suggest that higher intensity but perhaps less frequent periods of storminess are not necessarily associated with a wetter climate, which may be exemplified during the Little Ice Age. This work shows that important high-resolution palaeoenvironmental information can be gleaned by XRF-analysis of peat accumulations in cold-temperate climates. Furthermore, these analyses in combination with other established techniques offer a novel and underused way to examine the climate record of the recent past on a decadal to millennial scale.

Acknowledgements The authors wish to thank the NERC-BGS opportunities fund and support from Dounreay Site Restoration Ltd, which led to the development of this project. HS was supported by a NERC-BUFI - University of Stirling joint studentship (NE/K501156/1). We would like to thank Dr Andrew Finlayson, Dr Mary McCulloch, Natasha Rolph and James 
Blaikie for invaluable assistance in the field. We are also grateful to Dr Chris Hayward for his guidance and support for our use of the electron microprobe at the School of GeoSciences,

The University of Edinburgh. Two anonymous reviewers are thanked for their comments.

\section{References}

Alexander LV, Tett SFB. 2005. Recent observed changes in severe storms over the United

Kingdom and Iceland. Geophysical Research Letters 32 : 1-4.

525

Allan R, Tett S, Alexander L. 2009. Fluctuations in autumn-winter severe storms over the British Isles: 1920 to present. International Journal of Climatology 29 : 357-371.

Andresen CS, Bjork S. 2005. Holocene climate variability in the Denmark Strait region.

Geografiska Annalar 1: 159-174.

531

Andresen CS, Bond G, Kuijpers A, Knutz PC, Björck S. 2005. Holocene climate variability at multidecadal time scales detected by sedimentological indicators in a shelf core NW off Iceland. Marine Geology 214: 323-338.

535

Athanasiadis PJ, Wallace JM, Wettstein JJ. 2010. Patterns of jet stream wintertime variability and their relationship to the storm tracks. Journal of Atmospheric Sciences 67: 1361-1381.

Auton CA, Gillespie MR, Lott G.K, McKervey JA, Milodowski AE, Stephenson MH. 2005. 
Dounreay district, BGS Commissioned Report CR/05/009. British Geological Survey,

542 Edinburgh.

543

544 Bakke J, Lie $\varnothing$, Nesje A, Dahl SO, Paasche $\varnothing$. 2005. Utilizing physical sediment variability in 545 glacier-fed lakes for continuous glacier reconstructions during the Holocene, northern 546 Folgefonna, western Norway. Journal of Quaternary Science 15: 161-176.

547

Bakke J, Lie $\varnothing$, Dahl SO, Nesje A, Bjune AE. 2008. Strength and spatial patterns of the

Holocene wintertime westerlies in the NE Atlantic region. Global and Planetary Change 60:

550 28-41.

551

Baker A, Hellstrom J, Kelly B, Mariethoz G, Trouet V. 2015. A composite annual-resolution stalagmite record of North Atlantic climate over the last three millennia. Scientific Reports 5: doi:10.1038/srep10307.

555

Balascio NL, D'Andrea WJ, Bradley RS. 2015. Glacier response to North Atlantic climate variability during the Holocene. Climate of the Past 11: 1587-1598.

558

Biester H, Keppler F, Putschew A, Martinez-Cortizas A, Petri M. 2004. Halogen retention, organohalogens, and the role of organic matter decomposition on halogen enrichment in two Chilean peat bogs. Environmental Science and Technology 38: 1984- 1991.

Blaauw M, Van Geel B, Van der Plicht J. 2004. Solar forcing of climatic changes during the mid-Holocene: indications from raised bogs in the Netherlands. The Holocene 14: 1-35. 
566 Blaauw M, Christen JA. 2011. Flexible paleoclimate age-depth models using an autoregressive gamma process. Bayesian Analysis 6: 457-474.

568

Blackford JJ, 1993. Peat bogs as sources of proxy climatic data: past approaches and future research. In Climatic change and human impact on the landscape. Studies in palaeoecology and environmental archaeology, Chambers FM (ed.). Chapman \& Hall: London; 47-56.

Booth RK, Jackson SL, Forman JE, Kutzbach EA, Bettis III, Kreig J, Wright DK. 2005. A severe centennial-scale drought in continental North America 4200 years ago and apparent global linkages. The Holocene 15: 321-328.

576 annually resolved Holocene proxy climate records: stacked Holocene peatland palaeo-water table reconstructions from northern Britain. Quaternary Science Reviews 25: 336-350.

Charman DJ, Barber KE, Blaauw M, Langdon PG, Mauquoy D, Daley TJ, Hughes PDM, Karofeld E. 2009. Climate drivers for peatland paleoclimate reconstructions. The Holocene 17: $217-227$.

Charman DJ. 2010. Centennial climate variability in the British Isles during the mid-late Holocene. Quaternary Science Reviews 29: 1539-1554. 
590

591

592

593

594

595

596

597

598

599

600

601

602

603

604

605

606

607

608

609

610

Cheng X, Xie S-P, Tokinaga H, Du Y. 2011. Interannual Variability of High-Wind Occurrence over the North Atlantic. Journal of Climate 24: 6515-6527.

Clarke M, Rendell H, Tastet J-P. 2002. Late-Holocene sand invasion and North Atlantic storminess along the Aquitaine coast, southwest France. The Holocene 12: 231-238.

Clarke ML, Rendell HM. 2009. The impact of North Atlantic storminess on western European coasts: A review. Quaternary International 195: 31-41.

Dawson AG, Elliot L, Mayewski P, Lockett P, Noone S, Hickey K, Holt T, Wadhams P, Foster I. 2003. Late Holocene North Atlantic climate 'seesaws', storminess changes and Greenland ice sheet (GISP2) paleoclimates. The Holocene 13: 381-392.

Dawson AG, Mcllveny J, Warren J. 2010. Winter Gale Day Frequency in Shetland and Faeroes, AD 1866-1905: Links to Sea Ice History and the North Atlantic Oscillation. Scottish Geographical Journal, 126: 141 - 152.

De Jong R, Björck S, Björckman L, Clemmensen LB. 2006. Storminess variation during the last 6500 years as reconstructed from an ombotrophic peat bog in Halland, Southwest Sweden. Journal of Quaternary Science 21: 905-919.

De la Vega-Leinert AC, Keen DH, Jones R L, Wells JM, Smith DE. 2000, Mid-Holocene environmental changes in the Bay of Skaill, Mainland Orkney, Scotland: an integrated 
Di Rita F, Magri D. 2009. Holocene drought, deforestation and evergreen vegetation development in the central Mediterranean: A 5500 year record from Lago Alimini,Piccolo, Apulia, southeast Italy. The Holocene 19: 295-306.

617

Dugmore AJ, Larsen G, Newton, AJ. 1995a. Seven tephra isochrones in Scotland. The

Holocene 5: 257-266.

620

621

Dugmore AJ, Cook GT, Shore JS, Newton AJ, Edwards KJ, Larsen G. 1995b. Radiocarbon Dating Tephra Layers in Britain and Iceland. Radiocarbon 37: 379-388.

623

624

Genty D, Blamart D, Ghaleb B, Plagnes V, Causse C, Bakalowicz M, Melières MA, Zouari K, 625

Chkir N. 2006. Timing and Dynamics of the Last Deglaciation from European and North African $\delta^{13} \mathrm{C}$ stalagmite profiles - Comparison with South-Hemisphere stalagmite records. Quaternary Science Review 25: 2118-2142.

628

Hanna E, Cappelen J, Allan R, Jónsson T, Le Blanq F, Lillington T, Hickey K. 2008. New insights into North European and North Atlantic surface pressure variability, storminess, and related climate change since 1830. Journal of Climate 21: 6739-6766. cyclones: A chronology from cliff-top storm deposits. Quaternary International 195: 42-52. 
636 Haug GH, Hughen KA, Sigman DM, Petersen LC, Röhl U. 2001. Southward migration of the

637 Intertropical Convergence Zone through the Holocene. Science 293: 1304-1308.

638

639

Hayward C. 2013. High spatial resolution electron probe microanalysis of tephras and melt

640

inclusions without beam-induced chemical modification. The Holocene 22: 119-125.

641

642

Hughes PDM, Mauquoy D, Barber KE, Langdon PG. 2000. Mire-development pathways and

643

paleoclimatic records from a full Holocene peat archive at Walton Moss, Cumbria, England.

644

The Holocene 10: 465-479.

645

646

Hunt JB, Hill PG. 1993. Tephra geochemistry: a discussion of some persistent analytical

647 problems. The Holocene 3: 271-278.

648

649

Hurrell JW. 1995. Decadal Trends in the North Atlantic Oscillation: Regional Temperatures

650 and Precipitation. Science 269 : 676-679.

651

652

Hurrell J W, Kushnir Y, Ottersen G, Visbeck M. 2003. An Overview of the North Atlantic

653

Oscillation. In The North Atlantic Oscillation: Climatic Significance and Environmental Impact

654

Hurrell JW, Kushnir Y, Ottersen G, Visbeck M. (eds.). American Geophysical Union:

655

Washington, D. C.; 1-35.

656

657 Larsen DJ, Miller GH, Geirsdóttir Á, Ólafsdóttir S. 2012. Non-linear Holocene climate evolution in the North Atlantic: a high-resolution, multi-proxy record of glacier activity and 
659

660

661

662

663

664

665

666

667

668

669

670

671

672

673

674

675

676

677

678

679

680

681

682

environmental change from Hvítárvatn, central Iceland. Quaternary Science Reviews 39: 1425.

McDermott F, Mattey DP, Hawkesworth C. 2001. Centennial-scale Holocene climate variability revealed by a high-resolution speleothem delta 0-18 record from SW Ireland.

Science 294: 1328-1331.

Mcllvenny JD, Muller FLL, Dawson A. 2013. A 7600-year sedimentary record of climatic instability in Dunnet Nay, North Scotland. Marine Geology 335: 100-113.

Mann ME, Jones PD. 2003. Global surface temperatures over the past two millennia.

Geophysical Research Letter, 30: 10.1029/2003GL017814.

Mauri A, Davis BAS, Collins PM, Kaplan JO. 2014. The influence of atmospheric circulation on the mid-Holocene climate of Europe: a data-model comparison. Climates of the Past 10: $1925-1938$.

Mayewski PA, Rohling EE, Stager JC, Karlen W, Maasch KA, Meeker LD, Meyerson EA, Gasse F, Van Kreveld S, Holmgren K, Lee-Thorp J, Rosqvist G, Rack F, Staubwasser M, Schneider RR, Steig EJ. 2004. Holocene climate variability. Quaternary Research 62: 243-255.

Metcalfe SE, Barron JA, Davies SJ. 2015. The Holocene history of the North American

Monsoon: known knowns and known unknowns in understanding its spatial and temporal complexity. Quaternary Science Reviews 120: 1-27. 
Moreno j, Fatela F, Leorri E, Araújo MF, Moreno F, De la Rosa J, Freitas MC, Valente T, 685 Corbett R. 2015. Bromine enrichment in marsh sediments as a marker of environmental changes driven by grand solar minima and anthropogenic activity (Caminha, NW of Portugal)

Science of the Total Environment 506-507: 554-566.

688

Newton AJ. 1996. Tephrabase: A Tephrochronological Database. Quaternary Newsletter 78:

690 8-13.

691

692

O'Brien SR, Mayewski PA, Meeker LD, Meese DA, Twickler MS, Whitlow SI. 1995. Complexity of Holocene climate as reconstructed from a Greenland ice core. Science 270: 1962-1964.

694

Oldfield F, Batterbee RW, Boyle JF, Cameron NG, Davis B, Evershed RP, McGovern AD, Jones 696 V, Thompson R. 2010. Terrestrial and aquatic ecosystem responses to the late Holocene 697 climate change recorded in the sediments of Lochan Uaine, Cairngorms, Scotland.

Quaternary Science Reviews 29: 1040-1054.

699

700

Olsen J, Anderson NJ, Knudsen MF. 2012. Variability of the North Atlantic Oscillation over 701 the past 5200 years. Nature Geoscience 5: 808-812.

702

Orme LC, Davies SJ, Duller GAT. 2015. Reconstructed centennial variability of Late Holocene storminess from Cors Fochno, Wales, UK. Journal of Quaternary Science 30: 478-488. 
Orme LC, Reinhardt L, Jones RT, Charman DJ, Barkwith A, Ellis MA. 2016. Aeolian sediment reconstructions from the Scottish Outer Hebrides: Late Holocene storminess and the role of the North Atlantic Oscillation. Quaternary Science Reviews 132: 15-25.

Pinto JG, Zacharias S, Fink AH, Leckebusch GC, Ulbrich U. 2009. Factors contributing to the development of extreme North Atlantic cyclones and their relationship with the NAO.

Climate Dynamics 32: 711-737.

Reimer PJ, Bard E, Bayliss AJ, Beck W, Blackwell PG, Bronk Ramsey C, Buck CE, Cheng H, Edwards RL, Friedrich M, Grootes PM, Guilderson TP, Haflidason H, Hajdas I, Hatté C, Heaton TJ, Hoffmann DL, Hogg AG, Hughen KA, Kaiser KF, Kromer B, Manning SW, Niu M, Reimer RW, Richards DA, Marian Scott EM, Southon JR, Staff RA, Turney CSM, Van der Plicht J. 2013. INTCAL13 and MARINE13 Radiocarbon Age Calibration Curves 0-50,000 years cal. BP. Radiocarbon 55: 1869-1887.

Sabatier P, Dezileau L, Colin C. 2012. 7000 years of paleostorm activity in the NW Mediterranean Sea in response to Holocene climate events. Quaternary Research 77: 1-11.

Sander R, Keene WC, Pszenny AAP, Arimoto R, Ayers GP, Baboukas E, Cainey JM, Crutzen PJ, Duce RA, Hönninger G, Huebert BJ, Maenhaut W, Mihalopoulos N, Turekian VC, Van Dingenen R. 2003. Inorganic bromine in the marine boundary layer: a critical review. Atmospheric Chemistry and Physics 3: 1301-1336 

80

Stuiver M, Reimer PJ. 1993. Extended 14C database and revised CALIB radiocarbon calibration program. Radiocarbon 35: 215-230.

Swindles G, Plunkett G, Roe HM. 2007. A delayed response to solar forcing at 2800 cal. BP: multiproxy evidence from three Irish peatlands. The Holocene 17: 177-182.

\section{Sommerville AA, Hansom JD, Sanderson DCW, Housley RA. 2003. Optically stimulated} luminescence dating of large storm events in Northern Scotland. Quaternary Science Reviews 22: 1085-1092.

\section{Strong C, Davis RE. 2008. Variability in the position and strength of winter jet stream cores} related to Northern Hemisphere teleconnections. Journal of Climatology 21: 584-592.

Tipping R, Bradley R, Sanders J, McCulloch R, Wilson R. 2012. Moments of crisis: climate change in Scottish prehistory. Society of Antiquaries of Scotland 142: 9-25.

Tisdall E, McCulloch R, Sanderson D, Simpson I, Woodward N. 2013. Living with sand: A record of landscape change and storminess during the Bronze and Iron Ages Orkney, Scotland. Quaternary International 308-309: 205-215. 
Overturning Circulation during the last millennium: Reconciling contradictory proxy records of NAO variability. Global and Planetary Change 84-85: 48-55.

756

757 Turner TE, Swindles GT, Roucoux KH. 2014. Late Holocene ecohydrological and carbon dynamics of a UK raised bog: impact of human activity and climate change. Quaternary

Science Reviews 84: 65-85.

760

Vliet-Lanoë B, Penaud AI, Hénaff A, Delacourt C, Fernane A, Goslin JRM, Hallégouët B, Le

Cornec E. 2014. Middle-to-late Holocene storminess in Brittany (NW France): Part II - the chronology of events and climate forcing, Holocene 24: 296-310.

Walczak IW, Baldini JUL, Baldini LM, McDermott F, Marsden S, Standish CD, Richards DA,

Andreo B, Slater J. 2015. Reconstructing high-resolution climate using CT scanning of

unsectioned stalagmites: A case study identifying the mid-Holocene onset of the

Mediterranean climate in southern Iberia. Quaternary Science Reviews 127: 117-128.

Wang XL, Zwiers FW, Swail VR, Feng Y. 2009. Trends and variability of storminess in the

Northeast Atlantic region. 1874-2007. Climate Dynamics 33: 1179-1195.

Wang T, Surge D, Mithen S. 2012. Seasonal temperature variability of the Neoglacial (33002500 BP) and Roman Warm Period (2500-1600 BP) reconstructed from oxygen isotope ratios of limpet shells (Patella vulgata), Northwest Scotland. Palaeogeography, 
Woollings T, Hoskins B, Blackburn M, Berrisford P. 2008. A new Rossby wave-breaking interpretation of the North Atlantic Oscillation. Journal of the Atmospheric Sciences 65: 609626.

781

782

Woollings T, Hannachi A, Hoskins B. 2010. Variability of the North Atlantic eddy-driven jet stream. Quarterly journal of the Royal Meteorological Society 136: 856-868.

784

Zaccone C, Cocozza C, Shotyk W, Miano TM. 2008. Humic acids role in Br accumulation along two ombrotrophic peat bog profiles. Geoderma, 146: 26-31.

\section{List of Figures}

790

Figure 1: The preferred positions of the Polar Front Jet Stream and the corresponding phases of the NAO). White lines - Polar Front (i.e. average southern winter limit of Polar air masses). Grey long-dashed line - mean position of jet stream core between 1958 and 2006 (from Strong \& Davis, 2008). Coloured arrows -- approximate position of Polar vortex winds (colours match storms). Mode A dominates during strongly positive NAO phases; mode $\mathrm{B}_{1}$ or $\mathrm{B}_{2}$ dominates during strongly negative NAO. Neutral NAO phase (neither positive or negative) equates to a weak jet stream, with much-reduced storm frequency probably along negative $N A O$ tracks $\left(B_{1}, B_{2}\right)$.

Figure 2: A) Location map showing the study site in Northern Scotland. B) Detailed map of peat coring site near the Burn of Shebster. [Grid ticks are in British National Grid.] C) 
801

802

803

804

805

806

807

808

809

810

811

812

813

814

815

816

817

818

819

820

821

822

\section{1} 2

Average climatological conditions (1981-2010) at the nearest long-running weather station (Wick Airport; 58.454 N, 3.089 W; 36 m asl). Mean monthly air temperature (maximum and minimum) and normal wind speed envelope (at $10 \mathrm{~m}$ ) plotted on the same axis. Mean monthly precipitation shown as blue bars. [Data from metoffice.gov.uk]. Note the marked seasonality in average wind strength, peaking in winter (Dec-Mar).

Figure 3: Shebster stratigraphy, $\mathrm{LOI}_{550}$, Mire Surface Wetness, Bromine (ratio of $\mathrm{Br}$ / Inc + Coh) and BACON age/depth model.

Figure 4: Shebster Mire Surface Wetness, Bromine, 5000-yr glacier record from Folgefanna in Southern Norway (Bakke et al., 2008), reconstructed 5000-yr NAO index based on a lakesediment core in SW Greenland (Olsen et al., 2012), Scottish speleothem record (Baker et al., 2015) and Iberian speleothem record (Walkzak et al., 2015). The Hekla 4 tephra layer is indicated by a grey dotted line.

\section{List of Tables}

Table 1: Radiocarbon dates and ages for the $\mathrm{H} 4$ tephra layer correlated to the Shebster record.

${ }^{14} \mathrm{C}$ dates have been calibrated using CALIB Rev. 7.10 (Stuiver and Reimer, 1993) and IntCal 13.14c. (Reimer et al., 2013). 
Figure 1

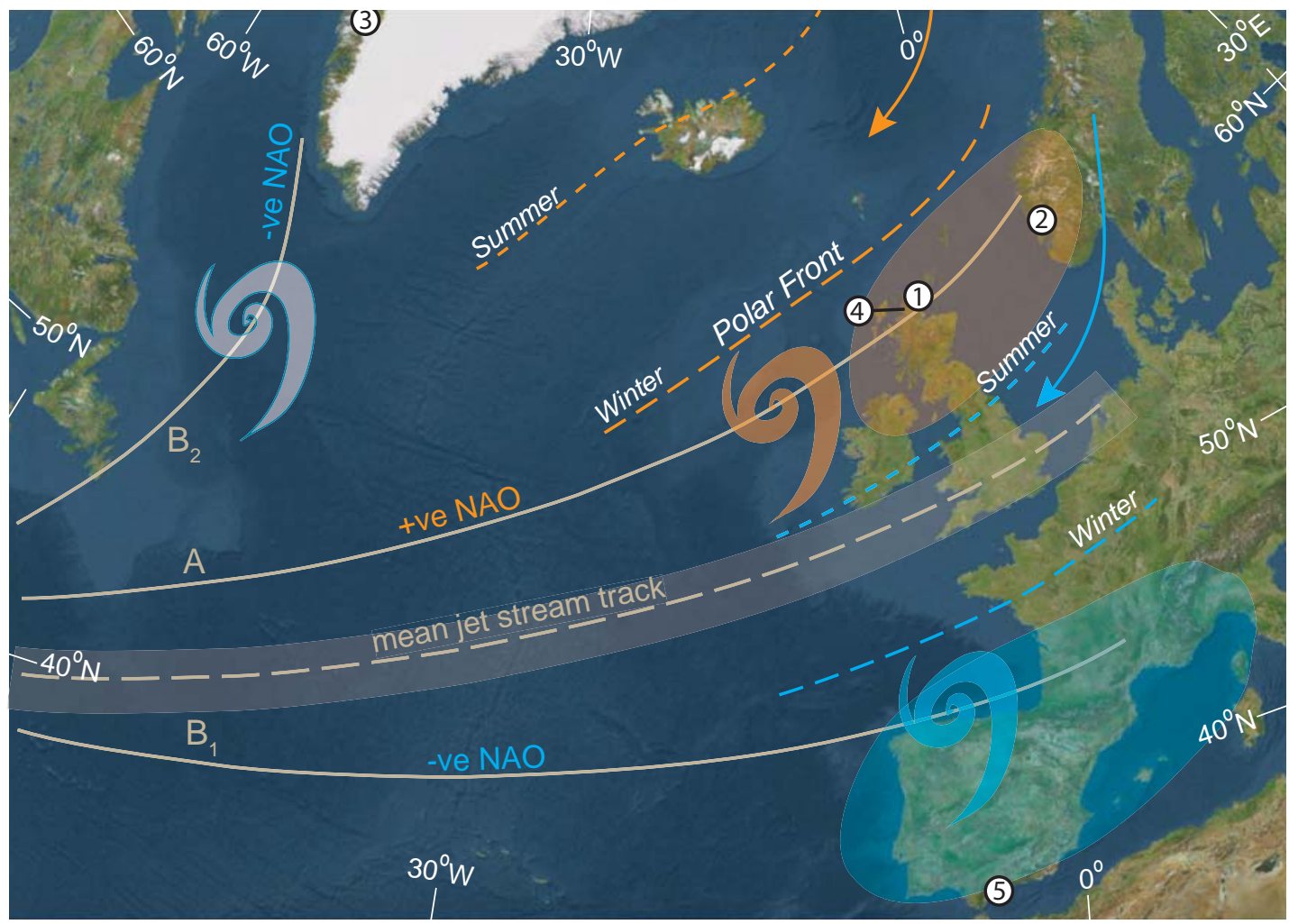


Figure 2
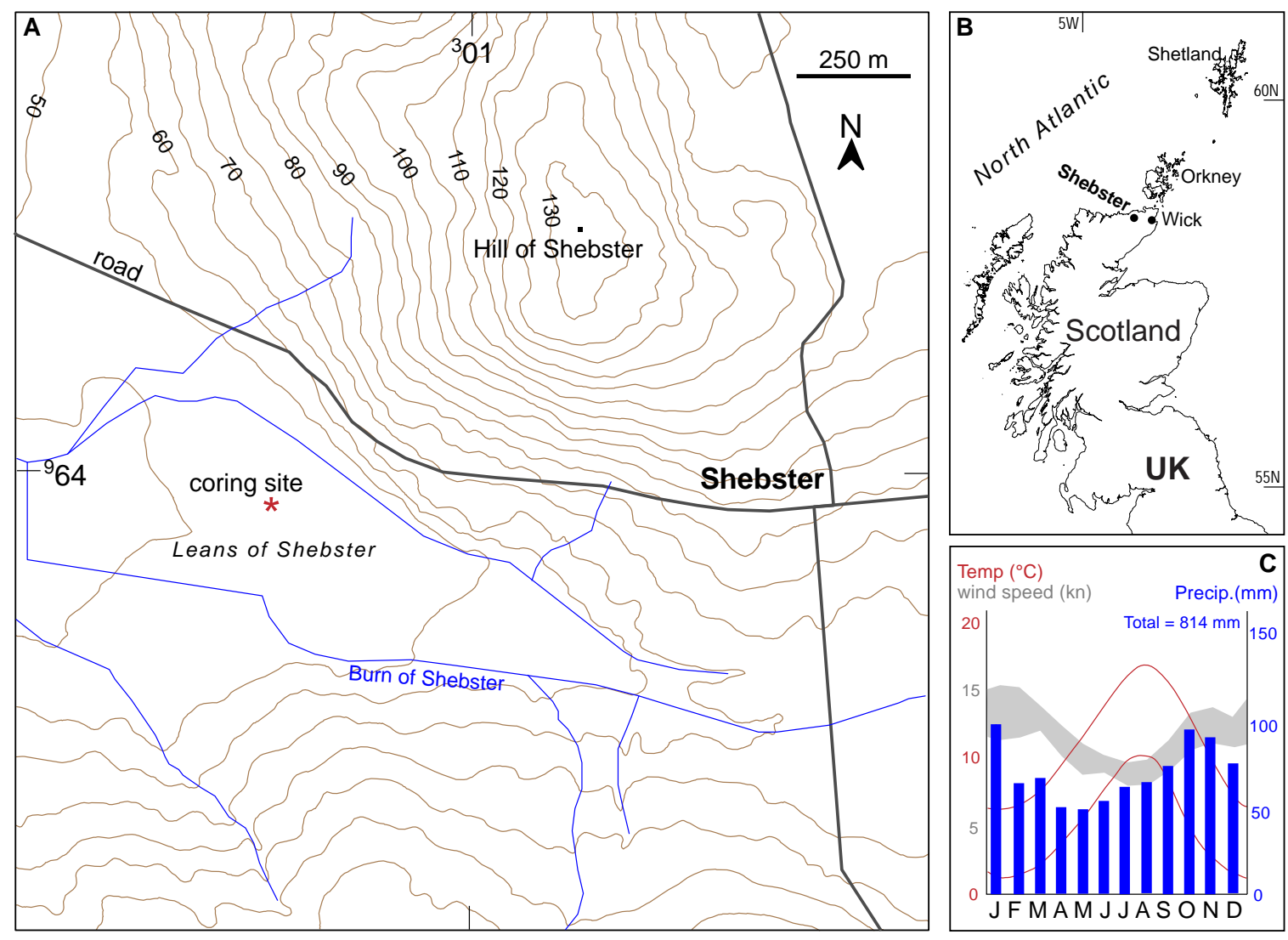

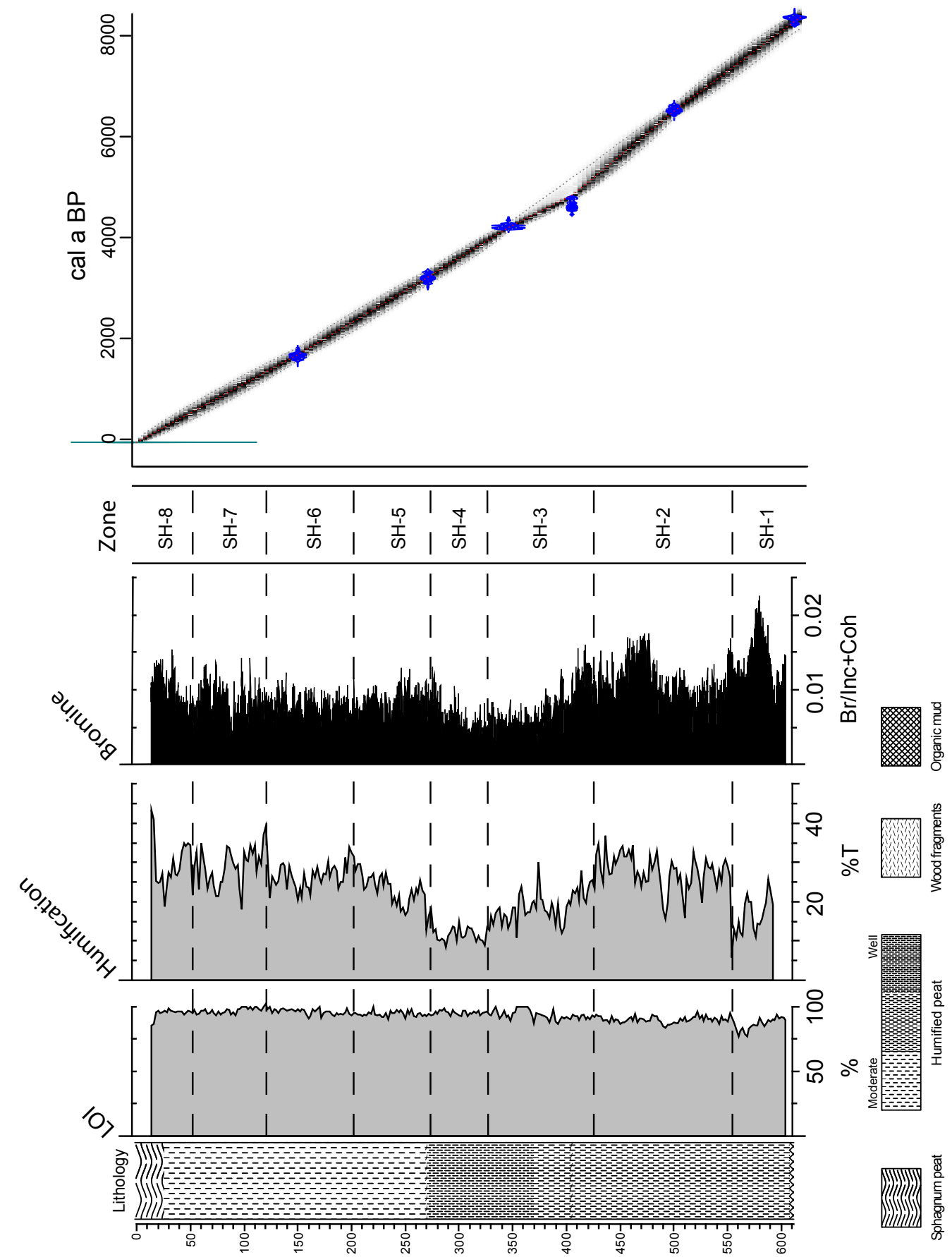

(u०) प1dəव

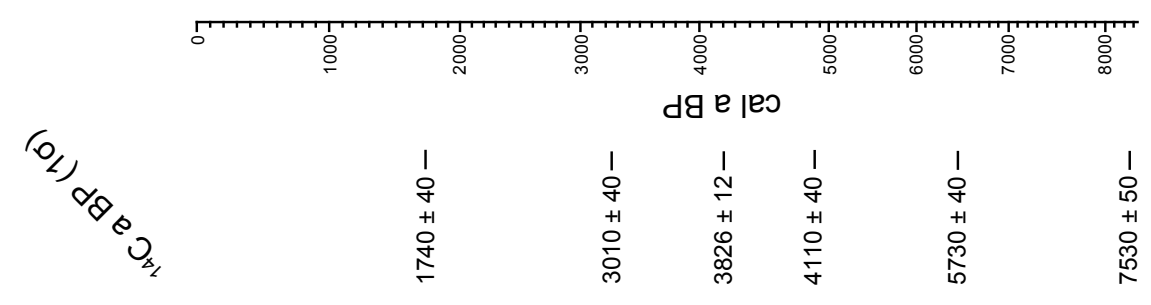

민
$\frac{0}{5}$
$\frac{5}{1}$ 


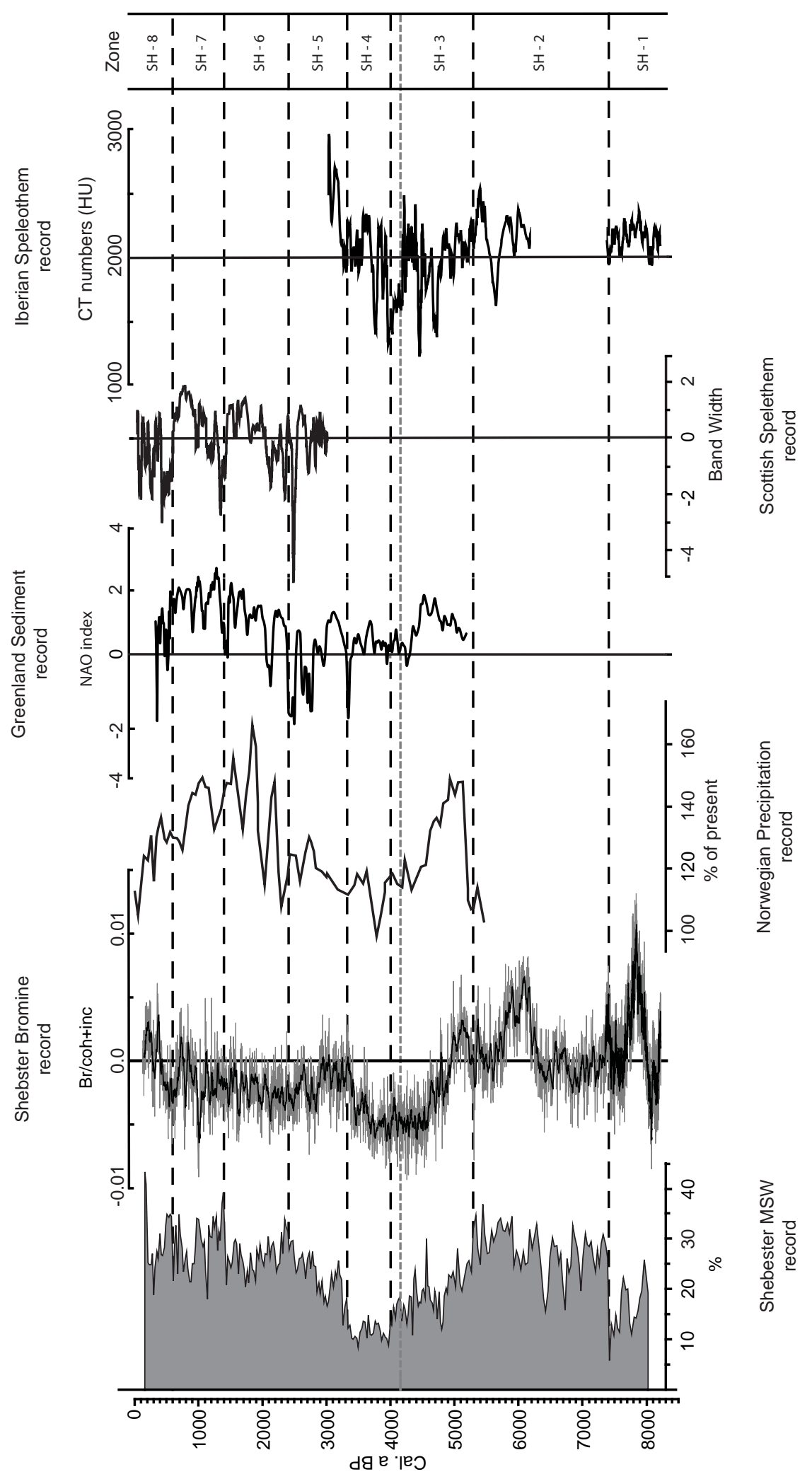


Table 1: Radiocarbon dates and ages for the $\mathrm{H} 4$ tephra layer correlated to the Shebster record. ${ }^{14} \mathrm{C}$ dates have been calibrated using CALIB Rev. 7.10 (Stuiver and Reimer, 1993) and IntCal 13.14c. (Reimer et al., 2013).

\begin{tabular}{cccccc}
\hline $\begin{array}{c}\text { Depth } \\
(\mathrm{cm})\end{array}$ & $\begin{array}{c}{ }^{14} \mathrm{C} \text { a BP } \\
(1 \sigma)\end{array}$ & $\delta^{13} \mathrm{CPPB}_{\mathrm{VP}} \%$ & $\begin{array}{c}\text { cal a BP } \\
(1 \sigma)^{2}\end{array}$ & $\begin{array}{c}\text { Weighted } \\
\text { Mean Age } \\
(\mathrm{cal} \text { a BP })^{3}\end{array}$ & Laboratory Code \\
\hline 150 & $1740 \pm 40$ & -28.3 & $1606-1706$ & 1679 & Beta 251972 \\
271 & $3010 \pm 40$ & -28.0 & $3083-3322$ & 3215 & Beta 251973 \\
346 & $3826 \pm 12^{1}$ & $\mathrm{n} / \mathrm{a}$ & $4159-4241$ & 4199 & $\mathrm{~N} / \mathrm{A}$ \\
405 & $4110 \pm 40$ & -29.4 & $4532-4802$ & 4841 & Beta 251974 \\
500 & $5730 \pm 40$ & -25.6 & $6454-6601$ & 6507 & Beta 251975 \\
612 & $7530 \pm 50$ & -24.7 & $8320-8403$ & 8286 & Beta 251976 \\
\hline
\end{tabular}

${ }^{114} \mathrm{C}$ age for Hekla 4 cryptotephra layer (Dugmore et al., 1995b)

${ }^{2}$ Calibrated ages produced using Calib Ver.7.1 (Stuiver and Reimer, 1993) and IntCal13 (Reimer et al., 2013)

${ }^{3}$ Weighted mean ages produced using BACON Bayesian age-depth program (Blaauw and Christen, 2011) 